\title{
Cholesterol oxides inhibit cholesterol esterification by lecithin:cholesterol acyl transferase
}

\author{
Eder de Carvalho Pincinato², Patricia Moriel $^{3}$, *Dulcinéia Saes Parra Abdalla1
}

${ }^{1}$ Department of Clinical and Toxicological Analysis, Faculty of Pharmaceutical Sciences, University of São Paulo, ${ }^{2}$ Mackenzie Presbyterian University, ${ }^{3}$ Department of Clinical Pathology, Faculty of Medical Sciences, State University of Campinas

\begin{abstract}
Cholesterol oxides are atherogenic and can affect the activity of diverse important enzymes for the lipidic metabolism. The effect of 7 $\beta$-hydroxycholesterol, 7-ketocholesterol, 25-hydroxycholesterol, cholestan-3 $\beta, 5 \alpha, 6 \beta$-triol,5,6 $\beta$-epoxycholesterol, 5,6 $\alpha$-epoxycholesterol and $7 \alpha$-hydroxycholesterol on esterification of cholesterol by lecithin:cholesterol acyl transferase (LCAT, EC 2.3.1.43) and the transfer of esters of cholesterol oxides from high density lipoprotein (HDL) to low density lipoproteins (LDL) and very low density lipoproteins (VLDL) by cholesteryl ester transfer protein (CETP) was investigated. HDL enriched with increasing concentrations of cholesterol oxides was incubated with fresh plasma as source of LCAT. Cholesterol and cholesterol oxides esterification was followed by measuring the consumption of respective free sterol and oxysterols. Measurements of cholesterol and cholesterol oxides were done by gas-chromatography. ${ }^{14} \mathrm{C}$-cholesterol oxides were incorporated into $\mathrm{HDL}_{2}$ and $\mathrm{HDL}_{3}$ subfractions and then incubated with fresh plasma containing LCAT and CETP. The transfer of cholesterol oxide esters was followed by measuring the ${ }^{14} \mathrm{C}$-cholesterol oxide-derived esters transferred to LDL and VLDL. All the cholesterol oxides studied were esterified by LCAT after incorporation into HDL particles, competing with cholesterol by LCAT. Cholesterol esterification by LCAT was inversely related to the cholesterol oxide concentration. The esterification of ${ }^{14} \mathrm{C}$-cholesterol oxides was higher in $\mathrm{HDL}_{3}$ and the transfer of the derived esters was greater from $\mathrm{HDL}_{2}$ to LDL and VLDL. The results suggest that cholesterol esterification by LCAT is inhibited in cholesterol oxide-enriched HDL particles. Moreover, the cholesterol oxides-derived esters are efficiently transferred to LDL and VLDL. Therefore, we suggest that cholesterol oxides may exert part of their atherogenic effect by inhibiting cholesterol esterification on the HDL surface and thereby disturbing reverse cholesterol transport.
\end{abstract}

Uniterms: Cholesterol/oxides. Cholesterol/acyl transferase. Lecithin. Protein/cholesteryl ester transfer. Lipoprotein/high density. Cholesterol/reverse transport.

Os óxidos de colesterol são aterogênicos e podem afetar a atividade de diversas enzimas importantes para o metabolismo lipídico. Este estudo investigou o efeito dos óxidos 7 $\beta$-hidroxicolesterol, 7-cetocolesterol, 25-hidroxicolesterol, colestan-3 $\beta, 5 \alpha, 6 \beta$-triol, 5,6 6 -epoxicolesterol, 5,6 $\alpha$-epoxicolesterol e 7 $\alpha$-hidroxicolesterol na esterificação do colesterol por ação da lecitina colesterol aciltransferase (LCAT, EC 2.3.1.43) e a posterior transferência dos óxidos esterificados da lipoproteína de alta densidade (HDL) para as lipoproteínas de baixa densidade (LDL) e muito baixa densidade (VLDL) mediada pela proteína de transporte de éster de colesterol (CETP). Para atingir os objetivos, HDL enriquecida com concentrações crescentes de óxidos de colesterol foi incubada com plasma fresco pobre em lipoproteínas, como fonte de LCAT; posteriormente a esterificação do colesterol e dos óxidos de colesterol foi medida pelo consumo do colesterol livre e dos óxidos livres presentes na HDL. As determinações de colesterol e dos óxidos de colesterol foram realizadas por cromatografia gasosa. ${ }^{14} \mathrm{C}$-óxidos de colesterol foram incorporados nas subfrações $\mathrm{HDL}_{2}$ e $\mathrm{HDL}_{3}$ e posteriormente incubados com plasma fresco, contendo LCAT e CETP. A transferência dos ésteres de óxidos de colesterol foi medida e quantificada pela presença desses ésteres na LDL e VLDL. Todos os óxidos de colesterol estudados foram esterificados pela LCAT após incorporação nas partículas de HDL e competiram com a esterificação do colesterol nativo. A esterificação do colesterol pela LCAT foi inversamente relacionada à concentração de óxidos de

\footnotetext{
*Correspondence: D. S. P. Abdalla. Faculdade de Ciências Farmacêuticas, Universidade de São Paulo, Av. Prof. Lineu Prestes, 580, Cidade Universitária, 05508-900 - São Paulo - SP, Brasil. E-mail: dspa@usp.br
} 
colesterol. A esterificação dos óxidos de colesterol foi maior na $\mathrm{HDL}_{3}$ e a transferência desses ésteres foi maior a partir da $\mathrm{HDL}_{2}$ para a LDL e VLDL. Estes resultados indicam que a esterificação do colesterol pela LCAT é inibida nas partículas de HDL enriquecidas com óxidos de colesterol e que os ésteres de óxidos de colesterol são eficientemente transferidos para a LDL e VLDL. Portanto, sugere-se que os óxidos de colesterol exercem parte de seu efeito aterogênico pela inibição da esterificação do colesterol na superfície da HDL, causando um distúrbio no transporte reverso do colesterol, além de aumentar o potencial aterogênico da LDL e VLDL.

Unitermos: Colesterol/óxidos. Colesterol/aciltransferase. Lecitina. Proteína/de transporte de éster de colesterol. Lipoproteína/de alta densidade. Colesterol/transporte reverso.

\section{INTRODUCTION}

High density lipoprotein (HDL) is the only antiatherosclerotic lipoprotein in plasma (Kawano et al., 2008) and plays an important role in the reverse cholesterol transport by removing cholesterol from peripheral cells to the liver and steroidogenic organs (Fielding and Fielding, 1995; Von Eckardstein, 1996; Oram and Yokoyama, 1996). There is a widespread view that HDL protects against the development of atherosclerosis and counteracts the effects of LDL by removing cholesterol from cells of the arterial intima, thus preventing the formation of foam cells (Fielding, Fielding, 1995). In a specific pathway pre $\beta 1-H D L$ (a HDL subfraction), interacts with cell membranes and takes up cholesterol via ATP-binding cassette (ABC) A1 expressed on the cell surface (Kawano et al., 2008). The second major and critical step in reverse cholesterol transport is the esterification of cholesterol on the HDL surface in a reaction catalyzed by lecithin:cholesterol acyl transferase (LCAT; EC 2.3.1.43). LCAT catalyzes the transfer of sn-2 acyl group from phosphatidylcholine to cholesterol (Glomset, 1968; Aron et al., 1978; Fielding, 1990), resulting in the movement of the formed cholesteryl esters to the center of the HDL, leaving the particle surface depleted of cholesterol. This creates a concentration gradient that promotes the transfer of cholesterol from cell membranes to HDL. An increased rate of LCAT-catalyzed cholesterol esterification will, therefore, enhance the rate of reverse cholesterol transport (Barter, Rye, 1996). This process is followed by the transfer of cholesteryl esters from HDL to apo B-containing lipoproteins in exchange for triglycerides mediated by the cholesterol ester transfer protein (CETP) (Iglesias et al., 1996). This way, the cholesteryl esters formed in the HDL are mainly channeled to VLDL and LDL, and are finally removed primarily by the liver.

The interest on cholesterol oxides is mainly due to their various biological effects, such as, cytotoxicity, inhibition of HMG-CoA reductase activity, activation of ACAT, inhibition of LDL binding to cell receptors (Peng et al., 1991) as biomarker of oxidative stress (Ferderbar et al., 2007) and inhibition of cholesterol efflux from cells (Kilsdonk et al., 1995; Schroepfer, 2000).

Oxysterols are the 27-carbon products of cholesterol oxidation by both enzymatic and non-enzymatic mechanisms. Their roles on cholesterol homeostasis, as well as in diseases in which oxidative damage and lipid peroxidation are implicated (e.g. atherosclerosis), have been investigated (Van Reyk et al., 2006). However, considering that the reverse cholesterol transport is a protective pathway of lipoprotein metabolism against cholesterol accumulation in the body, and considering that this mechanism would be interfered by cholesterol oxides, we investigated the effect of cholesterol oxides on cholesterol esterification by LCAT and the transfer of resulting cholesteryl esters formed in HDL to VLDL and LDL by CETP.

\section{MATERIAL AND METHODS}

\section{Material}

Cholesterol oxides (7 $\beta$-hydroxyholesterol, 7-ketocholesterol, 25-hydroxycholesterol, cholestan-3 $\beta, 5 \alpha, 6 \beta$ triol, 5,6 6 -epoxycholesterol, 5,6 $\alpha$-epoxycholesterol and $7 \alpha$-hydroxycholesterol) were purchased from Steraloids, Inc. (Wilton $\mathrm{NH}, \mathrm{USA}$ ); ${ }^{14} \mathrm{C}$-cholesterol was obtained from Amersham, Inc (Arlington Heights, IL); methanol (99 \%), ethanol (99\%), chloroform (99\%), bis(trimethylsilyl)trifluoracetamide (BSTFA-98 \%), $N$-hexane, acid acetic diethyl ether and $N, N$,dimethylphormamide were purchased from Merck (Darmstadt, Germany); linoleic acid, lipoxidase from Glycine max (soybean), $\mathrm{Na}_{2}$ EDTA and $\mathrm{NaCl}$ were obtained from Sigma Aldrich (St. Louis, USA).

\section{Lipoprotein isolation}

Venous blood was obtained from overnight-fasted adult human volunteers. Blood was collected into $10 \mathrm{~mL}$ Vacutainer tubes containing EDTA ( $1 \mathrm{mg} / \mathrm{mL}$ blood). VLDL $(\mathrm{d}<1.0021)$ LDL $(1.021<\mathrm{d}>1.065)$, total HDL $(1.065<\mathrm{d}>1.210)$ and lipoprotein deficient serum (LPDS; 
$\mathrm{d}>1.210$ ) were separated by preparative sequential ultracentrifugation with a Beckman 40T rotor (Redgrave, 1975). $\mathrm{HDL}_{2}(1.065<\mathrm{d}>1.125)$ and $\mathrm{HDL}_{3}(1.125<\mathrm{d}>1.210)$ were separated from total HDL by saline gradient ultracentrifugation in a Hitachi 4 ST rotor (Redgrave, 1975). All the lipoproteins and the LPDS were exhaustively dialyzed at $4{ }^{\circ} \mathrm{C}$ against $0.15 \mathrm{M} \mathrm{NaCl} / 1 \mathrm{mM}-\mathrm{Na}_{2}$ EDTA, $\mathrm{pH} 7.4$.

\section{${ }^{14} \mathrm{C}$-cholesterol oxides formation}

To obtain ${ }^{14} \mathrm{C}$-cholesterol oxides, a solution containing $1.89 \mu \mathrm{mol}$ of ${ }^{14} \mathrm{C}$-cholesterol and $9.45 \mu \mathrm{mol}$ of linoleic acid in ether was prepared. Borate buffer $(0.2$ $\mathrm{M}, \mathrm{pH}$ 9.0) was added to the solution and mixed to form micelles. After the solvent evaporation, lipoxidase (EC 1.13.11.12 - 300.000 U) was added (Fruebis et al., 1992) and conjugated dienes kinetic formation was monitored at $234 \mathrm{~nm}$ (spectrophotometer UV-Vis U3000, Hitachi, Japan), to evaluate the lag phase of lipid peroxidation. When the lag phase was finished, more $300.000 \mathrm{U}$ lipoxidase were added to the system to ensure the total cholesterol oxidation (Esterbauer et al., 1992). The solution was mixed overnight and the cholesterol oxides were isolated from cholesterol and other lipids as described previously (Sevanian, Mcleod, 1987). In this procedure $68 \%$ of ${ }^{14} \mathrm{C}$-cholesterol was oxidized. The pool of ${ }^{14} \mathrm{C}$-cholesterol oxides yielded from ${ }^{14} \mathrm{C}$-cholesterol oxidation was used in all experiments.

\section{${ }^{14} \mathrm{C}$-cholesterol oxides and cholesterol oxides incorporation into HDL}

Non-labeled cholesterol oxide standards or the pool of ${ }^{14} \mathrm{C}$-cholesterol oxides $(0.15 \mu \mathrm{Ci} / \mathrm{mL})$ were added to glass vials and the solvent was evaporated under nitrogen. These cholesterol oxides were re-suspended in ethanol and a $2 \mathrm{~mL}$ solution of HDL ( $35 \mathrm{mg} / \mathrm{dL}$ cholesterol) was added. The mixture was incubated at $37^{\circ} \mathrm{C}$ for $3 \mathrm{~h}$ in a shaking water bath. An aliquot of red blood cells suspension was added as described (Oda et al., 1990) to adsorb the cholesterol and cholesterol oxides not incorporated into HDL.

\section{Esterification of cholesterol oxides (standards and radiolabeled)}

Cholesterol oxide-enriched HDL particles (along with radiolabeled cholesterol or cholesterol oxide standards) were incubated with lipoprotein deficient serum (LPDS, $60 \mu \mathrm{g} / \mathrm{mL}$ protein, source of LCAT) at $37^{\circ} \mathrm{C}$, for $1 \mathrm{~h}$, in a shaking water bath. Immediately afterwards, the reaction was stopped by placing the tubes in ice. Aliquots were collected at the moment of LPDS addition and at the end of specified incubation times and analyzed by GC-FID (Hewlett Packard, HP-6890) to measure cholesterol oxides and by cintilography to evaluate ${ }^{14} \mathrm{C}$-cholesterol oxides. For the chromatographic analyzes samples were derivatized to trimethylsilyl (TMS) ethers and $4 \mu \mathrm{L}$ aliquots were injected into the gas chromatograph equipped with flame ionization detector as described elsewhere (Sevanian et al., 1994).

\section{Transfer of ${ }^{14} \mathrm{C}$-cholesteryl oxide esters from HDL to apoB-containing lipoproteins}

${ }^{14} \mathrm{C}$-cholesterol-HDL subfractions $\left(\mathrm{HDL}_{2}\right.$ and $\mathrm{HDL}_{3}$, previously incubated with LCAT) were incubated with LDL (140 mg/dl cholesterol) and VLDL $(25 \mathrm{mg} / \mathrm{dL}$ cholesterol) for 6 hours at $37^{\circ} \mathrm{C}$. The reactions were stopped on ice and lipoproteins reisolated by sequential ultracentrifugation. Aliquots were extracted with chloroform:methanol (2:1) and the radioactivity analyzed in a liquid scintillation counter (Packard 1900 TR-liquid scintillation analyzer, Meriden, CT 06450). 5,5-Dithiobis-(2-nitrobenzoic acid (DTNB) was added in the transfer experiments to inhibit LCAT and $p$-chloromercuriphenylsulfonic acid (pCMPS) was added for CETP inhibition.

\section{Free and esterified ${ }^{14} \mathrm{C}$-cholesterol oxide analysis}

Free and esterified ${ }^{14} \mathrm{C}$-cholesterol oxides were separated by thin layer chromatography using a solvent mixture consisting of $n$-hexane/diethyl ether/acetic acid/methanol $(85: 20: 1: 1 ; \mathrm{v} / \mathrm{v} / \mathrm{v} / \mathrm{v})$ and the chromatographic plates were visualized using iodine vapor. The spots corresponding to free cholesterol and cholesteryl esters were scraped from the plates and re-suspended in scintillation solution (POPOP - 0,15 g; PPO - 5,0g; Triton - $500 \mathrm{~mL}$; toluene q.s.p $1000 \mathrm{~mL}$ ) to measure the radioactivity.

\section{Statistical Analysis}

Data are reported as means \pm SEM. Statistical analysis was performed by the Tukey test as a post-test after ANOVA, with $\mathrm{p}<0.05$ considered to be significant (Sigma Stat software).

\section{RESULTS AND DISCUSSION}

Cholesterol oxides incorporation into HDL is shown at Table I. The percentage of incorporation of cholesterol oxides into HDL ranged from 11 to $60 \%$ with the highest incorporation found for the 7-ketocholesterol and the lowest for cholestan-3b,5a,6b-triol (triol), the lowest incorporation 
of triol may be related to its higher hydrophilicity. All the cholesterol oxides incorporated into HDL were esterified by LCAT from human plasma (Figure 1). This is in accordance with data previously described for LCAT catalyzed esterification of oxysterols in discoidal bilayer particles (Nishida et al., 1993). However, the esterification yield varied among the different cholesterol oxides with the lowest esterification taking place with triol. This suggests that triol is not an efficient substrate for LCAT, possibly due to its higher hydrophilicity compared to the other cholesterol oxides, and/or steric hindrance from the 5,6-hydroxyl moieties, which may reduce interaction with the hydrophobic catalytic site of LCAT (Peelman et al., 1998)

TABLE I - Incorporation of cholesterol oxides into HDL

\begin{tabular}{lc}
\hline & incorporation into HDL (\%) \\
\hline cholesterol & - \\
cholestan-3 $\beta, 5 \alpha, 6 \beta$-triol & 11 \\
25-hydroxycholesterol & 53 \\
cholesteryl $\beta$-epoxide & 54 \\
$7 \alpha$-hydroxycholesterol & 43 \\
cholesteryl $\alpha$-epoxide & 56 \\
7 $\beta$-hydroxycholesterol & 40 \\
7-ketocholesterol & 60 \\
\hline
\end{tabular}

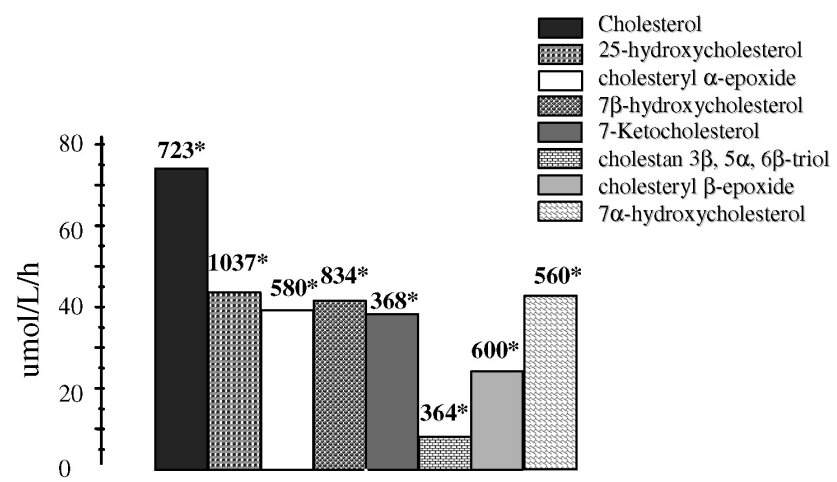

FIGURE 1 - Esterification rate of cholesterol oxides incorporated into HDL, in relation to an HDL particle containing no cholesterol oxides. *Initial concentrations of cholesterol oxides (uM) incorporated into HDL.

Figure 2 shows the esterification intensity of both cholesterol and cholesterol oxides in the same HDL particle. It is noteworthy that the esterification of cholesterol is affected by the presence of cholesterol oxides in HDL. Most of the cholesterol oxides, except the triol and $7 \alpha$-hydroxycholesterol, showed a trend for greater esterification compared to cholesterol. However, significant differences were observed only for 7-ketocholesterol and 5,6 $\beta$-epoxycholesterol. The most pronounced inhibition of cholesterol esterification by LCAT was induced by 7-ketocholesterol.
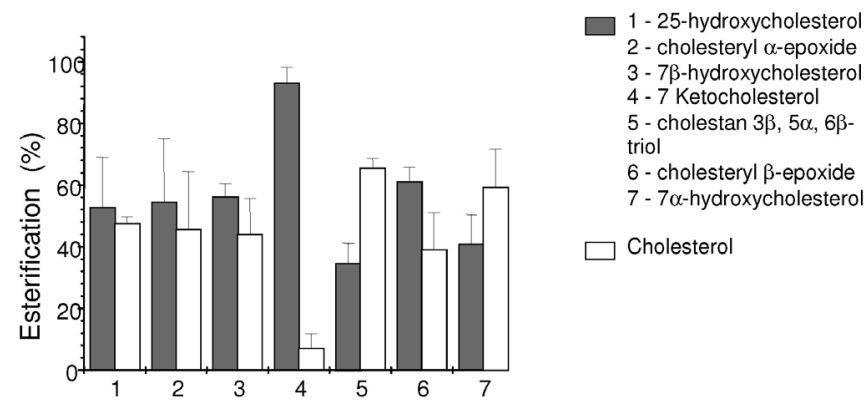

FIGURE 2 - Esterification (\%) of cholesterol and cholesterol oxides both in the same HDL particle. The relative esterification was calculated considering a sum of the esters formed from cholesterol and cholesterol oxides as $100 \%$ of esterification.

The esterification of oxysterols catalyzed by LCAT was also affected when examined in HDL subfractions. ${ }^{14} \mathrm{C}$-cholesterol oxide-enriched HDL subfractions showed different degrees of esterification efficiency. The ${ }^{14} \mathrm{C}$ cholesterol oxides esterification was higher in the $\mathrm{HDL}_{3}$ subfraction $(2.6 \pm 0.5 \mathrm{nCi}, \mathrm{n}=6)$ as compared to $\mathrm{HDL}_{2}(1.4$ $\pm 0.3 \mathrm{nCi}, \mathrm{n}=6$ ), as occurs for cholesterol esterification by LCAT. Accordingly, Fielding et al. (1989) proposed that the efflux of radiolabeled cholesterol from fibroblasts promoted by HDL, and its further esterification on this lipoprotein by LCAT, differed among HDL subfractions. The enhancement of LCAT activity was directly related with the increase of $\mathrm{HDL}_{3}$ and inversely correlated with $\mathrm{HDL}_{2}$ (Dobiasova et al., 1991, 1992).

The investigation of the influence of cholesterol oxides concentration on cholesterol esterification showed that the inhibition of cholesterol esterification by LCAT was strongly dependent on cholesterol oxides concentration. As it can be seen at Table II, a concentration-dependent inhibition of cholesterol esterification was found, as the cholesterol oxide concentration increases in HDL particle.

Another important step for reverse cholesterol transport is the transfer of cholesteryl esters formed in HDL to the apo-B containing lipoproteins. Figures 3 and 4 show the transfer of labeled cholesterol oxides present in HDL subfractions to LDL and VLDL, respectively. ${ }^{14} \mathrm{C}-$ cholesterol oxides were first esterified in HDL enriched particle in the presence or absence of DTNB (5,5-Dithiobis-(2-nitrobenzoic acid), a LCAT inhibitor. Later, these cholesterol oxides-enriched HDL particles were separately incubated with LDL and VLDL and LPDS, as source of 
TABLE II - Dependence of cholesterol and cholesterol oxide esterification rate on cholesterol oxide concentration

\begin{tabular}{|c|c|c|c|}
\hline $\begin{array}{l}\text { Cholesterol } \\
\text { oxide }\end{array}$ & $\begin{array}{c}\text { Concentration } \\
\text { (uM) }\end{array}$ & $\begin{array}{l}\text { Cholesterol } \\
\text { esterification } \\
\text { rate } \\
\text { (umol/L/h) }\end{array}$ & $\begin{array}{c}\text { Cholesterol oxide } \\
\text { esterification rate } \\
\quad(\mathrm{umol} / \mathrm{L} / \mathrm{h})\end{array}$ \\
\hline \multirow{4}{*}{$\begin{array}{l}\text { 25-hydroxy- } \\
\text { cholesterol }\end{array}$} & 35 & 23.2 & 2.9 \\
\hline & 52 & 13.4 & 3.0 \\
\hline & 74.4 & 10.3 & 3.9 \\
\hline & 163 & 1.6 & 6.9 \\
\hline \multirow{4}{*}{$\begin{array}{l}\text { cholestan } 3 \beta \text {, } \\
5 \alpha, 6 \beta \text {-triol }\end{array}$} & 24.6 & 52.0 & 2.0 \\
\hline & 93 & 46.6 & 6.9 \\
\hline & 232 & 45.4 & 15.5 \\
\hline & 444 & 17.4 & 16.1 \\
\hline \multirow{4}{*}{$\begin{array}{l}\text { 7 } \alpha \text {-hydroxy- } \\
\text { cholesterol }\end{array}$} & 405 & 52.8 & 67.5 \\
\hline & 544 & 43.9 & 77.9 \\
\hline & 620 & 38.2 & 82.5 \\
\hline & 744 & 36.1 & 86.8 \\
\hline \multirow{4}{*}{$\begin{array}{l}5,6 \beta \text {-epoxy- } \\
\text { cholesterol }\end{array}$} & 152 & 38.4 & 5.1 \\
\hline & 348 & 35.6 & 17.6 \\
\hline & 487 & 36.6 & 65.6 \\
\hline & 1491 & 32.2 & 164.5 \\
\hline \multirow{4}{*}{ 7-ketocholesterol } & 187 & 38.4 & 54.2 \\
\hline & 343 & 35.7 & 100.0 \\
\hline & 603 & 24.8 & 148.6 \\
\hline & 1100 & 13.9 & 184.2 \\
\hline \multirow{4}{*}{$\begin{array}{l}\text { 7ß-hydroxy- } \\
\text { cholesterol }\end{array}$} & 91 & 54.2 & 13.4 \\
\hline & 98 & 53.1 & 14.0 \\
\hline & 209 & 45.1 & 27.9 \\
\hline & 397 & 35.1 & 39.5 \\
\hline \multirow{4}{*}{$\begin{array}{l}5,6 \alpha \text {-epoxy- } \\
\text { cholesterol }\end{array}$} & 64.5 & 165.0 & 20.9 \\
\hline & 497 & 165.9 & 162.3 \\
\hline & 1512 & 104.8 & 312.1 \\
\hline & 3338 & 92.7 & 609.8 \\
\hline
\end{tabular}

CETP, in the presence or absence of pCMPS ( $p$-chloromercuriphenylsulfonic acid) which inhibits CETP. The results show that DTNB efficiently inhibited esterification by LCAT, although pCMPS inhibited only $50 \%$ of CETP activity. The transfer of labeled cholesterol oxide esters from HDL to LDL and VLDL was similar for both particles (approximately $50 \%$ of the labeled substrates being transferred in each case), which were incubated separately with HDL. The transfer of radiolabeled cholesterol oxide esters was higher in $\mathrm{HDL}_{2}$ subfraction (approximately $50 \%$ ) as compared with $\mathrm{HDL}_{3}$ subfraction (approximately 13\%). This may be due either to the $\mathrm{HDL}_{2}$ subfraction containing more cholesteryl esters or by a major interaction of this particle with CETP, as proposed by Jonas (1991) for cholesterol transfer. The major esterification of cholesterol and cholesterol oxides in $\mathrm{HDL}_{3}$ dynamically modifies this subfraction to the form $\mathrm{HDL}_{2}$, which is a better substrate for CETP that transforms the $\mathrm{HDL}_{2}$ again into $\mathrm{HDL}_{3}$.
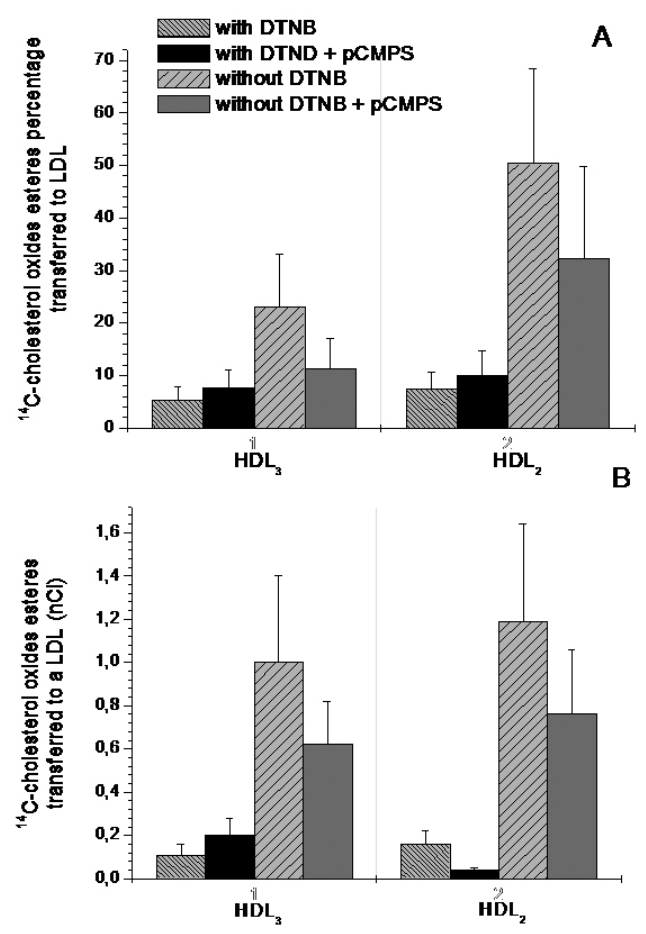

FIGURE 3 - Transfer of ${ }^{14} \mathrm{C}$-cholesterol oxide esters from $\mathrm{HDL}_{3}$ and $\mathrm{HDL}_{2}$ to LDL, (A) in $\%$ of ${ }^{14} \mathrm{C}$-cholesterol transferred and (B) in nCi. Both with DTNB (LCAT inhibitor), with DTNB plus pCMPS (CETP inhibitor), without DTNB and, without DTNB plus pCMPS.
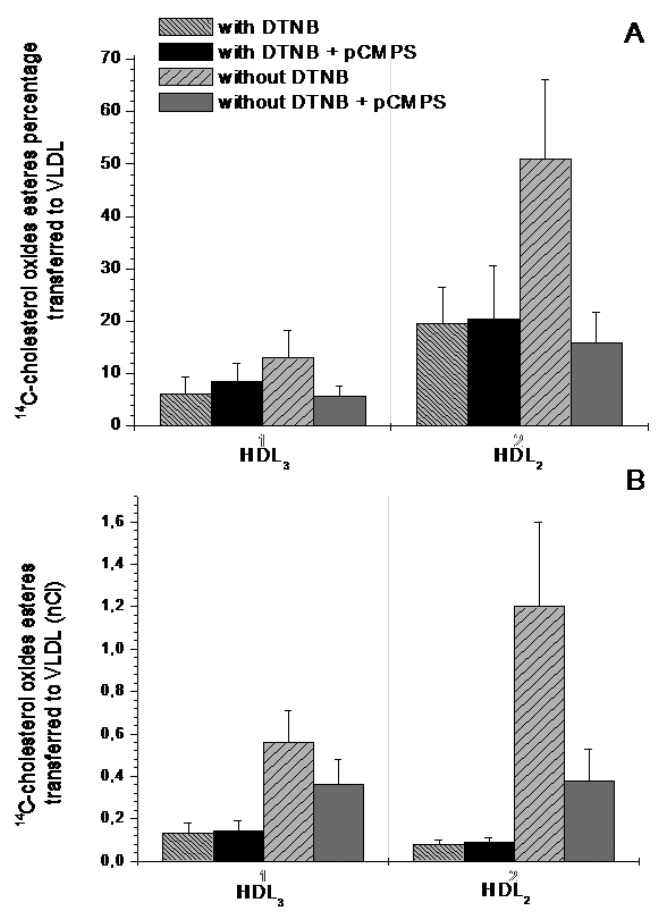

FIGURE 4 - Transfer of ${ }^{14} \mathrm{C}$-cholesterol oxide esters from $\mathrm{HDL}_{3}$ and $\mathrm{HDL}_{2}$ to VLDL, (A) in $\%$ of ${ }^{14} \mathrm{C}$-cholesterol transferred and (B) in nCi. Both with DTNB, with DTNB plus pCMPS , without DTNB and without DTNB plus pCMPS. 


\section{CONCLUSIONS}

In conclusion, this study shows that cholesterol oxides are esterified by LCAT and that the efficiency of esterification differs among the different cholesterol oxides present in HDL. Cholesterol oxides diminished the LCAT-catalyzed cholesterol esterification and this may have an important effect on reverse cholesterol transport. Thus, these data indicate that the effect of cholesterol oxides on cholesterol esterification in HDL and on transfer of these cholesteryl esters to LDL and VLDL may contribute to the atherogenicity of these oxysterols.

\section{AKNOWLEDGMENTS}

This work was supported by Fundação de Amparo à Pesquisa do Estado de São Paulo (FAPESP, grant 96/12164-0 to DSPA). Éder C. Pincinato was a fellowship holder of Fundação de Amparo à Pesquisa do Estado de São Paulo (FAPESP).

\section{REFERENCES}

ARON, L.; JONES, S.; FIELDING, C.J. Human plasma lecithincholesterol acyltransferase. Characterization of cofactordependent phospholipase activity. J. Biol. Chem. v.253, n.20, p.7220-7226, 1978.

BARTER, P.J.; RYE, K.A. Molecular mechanisms of reverse cholesterol transport. Curr. Opin. Lipidol., v.7, n.2, p.82-87, 1996.

DOBIASOVA, M.; STRIBRNA, J.; PRITCHARD, P.H.; FROHLICH, J.J. Cholesterol esterification rate in plasma depleted of very low and low density lipoproteins is controlled by the proportion of HDL2 and HDL3 subclasses: study in hypertensive and normal middle-aged and septuagenarian men. J. Lipid Res., v.33, n.10, p.1411-1418, 1992.

DOBIASOVA, M.; STRIBRNA, J.; SPARKS, D.L.; PRITCHARD, P.H.; FROHLICH, J.J. Cholesterol esterification rates in very low density lipoprotein- and low density lipoprotein-depleted plasma. Relation to high density lipoprotein subspecies, sex, hyperlipidemia, and coronary artery disease. Arterioscler. Thromb., v.11, n.1, p.64-70, 1991.

ESTERBAUER, H., GEBICKI, J., PUHL, H., JURGENS, G. The role of lipid peroxidation and antioxidants in oxidative modification of LDL. Free Radical Biol. Med., v.13, n.4, p.341-390, 1992.
FERDERBAR, S.; PEREIRA, E.C.; APOLINÁRIO, E.; BERTOLAMI, M.C.; FALUDI, A.; MONTE, O.; CALLIARI, L.E.; SALES, J.E.; GAGLIARDI, A.R.; XAVIER, H.T.; ABDALLA, D.S. Cholesterol oxides as biomarkers of oxidative stress in type 1 and type 2 diabetes mellitus. Diabetes Metab. Res. Rev., v.23, n.1, p.35-42, 2007.

FIELDING, C. J. Lecithin: cholesterol acyltransferase. In: ESFAHANI, M.; SWANEY, J. B. (Eds.). Advances in cholesterol research. New Jersey: Telford Press, 1990. p. 271-314.

FIELDING, C.J.; FIELDING, P.E. Molecular physiology of reverse cholesterol transport. J. Lipid Res. v.36, n.2, p.211-228, 1995.

FIELDING, P. E.; ISHIKAWA, Y.; FIELDING, C. J. Apolipoprotein E mediates binding of normal very low density lipoprotein to heparin but is not required for high affinity receptor binding. J. Biol. Chem., v.264, n.21, p.12462-6, 1989.

FRUEBIS, J., PARTHASARATHY, S., STEINBERG, D. Evidence for a concerted reaction between lipid hydroperoxides and polypeptides. Proc. Natl. Acad. Sci. USA, v.89, n.22, p.1058810592, 1992.

GLOMSET, J.A. The plasma lecithins:cholesterol acyltransferase reaction. J. Lipid Res. v.9, n.2, p.155-167, 1968.

IGLESIAS, A.; ARRANZ, M.; ALVAREZ, J.J.; PERALES, J.; VILLAR, J.; HERRERA, E.; LASUNCIÓN, M.A. Cholesteryl ester transfer activity in liver disease and cholestasis, and its relation with fatty acid composition of lipoprotein lipids. Clin. Chim. Acta., v.248, n.2, p.157-174, 1996.

JONAS, A. Lecithin-cholesterol acyltransferase in the metabolism of high-density lipoproteins. Biochim. Biophys. Acta., v.1084, n.3, p.205-220, 1991.

KAWANO, M.; NAGASAKA, S.; YAGYU, H.; ISHIBASHI, S. Pitavastatin decreases plasma prebeta1-HDL concentration and might promote its disappearance rate in hypercholesterolemic patients. J. Atheroscler. Thromb., v.15, n.1, p. 41-46, 2008.

KILSDONK, E.P.; MOREL, D.W.; JOHNSON, W.J.; ROTHBLAT, G.H. Inhibition of cellular cholesterol efflux by 25-hydroxycholesterol. J. Lipid Res., v.36, n.3, p.505-516, 1995. 
NISHIDA, H.I.; ARAI, H.; NISHIDA, T. Cholesterol ester transfer mediated by lipid transfer protein as influenced by changes in the charge characteristics of plasma lipoproteins. J. Biol. Chem., v.268, n.22, p.16352-16360, 1993.

ODA, H.; YAMASHITA, H.; KOSAHARA, K.; KUROKI, S.; NAKAYAMA, F. Esterified and total 7 alphahydroxycholesterol in human serum as an indicator for hepatic bile acid synthesis. J. Lipid Res., v.31, n.12, p.2209-2218, 1990.

ORAM, J.F.; YOKOYAMA, S. Apolipoprotein-mediated removal of cellular cholesterol and phospholipids. J. Lipid Res. v.37, n.12, p.2473-2491, 1996.

PEELMAN, F.; VINAIMONT, N.; VERHEE, A.; VANLOO, B.; VERSCHELDE, J.L.; LABEUR, C.; SEGURETMACE, S.; DUVERGER, N.; HUTCHINSON, G.; VANDEKERCKHOVE, J.; TAVERNIER, J.; ROSSENEU, M. A proposed architecture for lecithin cholesterol acyl transferase (LCAT): identification of the catalytic triad and molecular modeling. Protein Sci., v.7, n.3, p.587-599, 1998.

PENG, S.K.; HU, B.; MORIN, R.J. Angiotoxicity and atherogenicity of cholesterol oxides. J. Clin. Lab. Anal., v.5, n.2, p.144-152, 1991.;
REDGRAVE, T.G.; ROBERTS, D.C.; WEST, C.E. Separation of plasma lipoproteins by density-gradient ultracentrifugation. Anal. Biochem., v.65, n.1-2, p.42-49, 1975.

SCHROEPFER, G.J. JR. Oxysterols: modulators of cholesterol metabolism and other processes Physiol. Rev., v.80, n.1, p.361554,2000

SEVANIAN, A.; MCLEOD, L.L. Cholesterol autoxidation in phospholipid membrane bilayers. Lipids, v.22, n.9, p.627-636, 1987.

SEVANIAN, A.; SERAGLIA, R.; TRALDI, P.; ROSSATO, P.; URSINI, F.; HODIS, H. Analysis of plasma cholesterol oxidation products using gas- and high-performance liquid chromatography/mass spectrometry. Free Radic. Biol. Med., v.17, n.5, p.397-409, 1994.

VAN REYK, D.M.; BROWN, A.J.; HULT'EN, L.M.; DEAN, R.T.; JESSUP, W. Oxysterols in biological systems: sources, metabolism and pathophysiological relevance. Redox Rep., v.11, n.6, p.255-262, 2006.

VON ECKARDSTEIN, A. Cholesterol efflux from macrophages and other cells. Curr. Opin. Lipidol. v.7, n.5, p.308-319, 1996.

Received for publication on $26^{\text {th }}$ February 2008 Accepted for publication on $3^{\text {rd }}$ June 2009 